\title{
Peningkatan Ketrampilan Kreativitas Desain Grafis Digital Siswa SMU Menggunakan Aplikasi CANVA pada Ponsel Pintar
}

\author{
Fetty Tri Anggraeny ${ }^{1)}$, Henni Endah Wahanani' ${ }^{2)}$, Fawwaz Ali Akbar ${ }^{3)}$, \\ M. Ilham Prasetyo Raharjo ${ }^{4}$, Sandy Rizkyando ${ }^{5)}$
}

\author{
Informatika, Fakultas Ilmu Komputer, Universitas Pembangunan Nasional “Veteran” Jawa Timur \\ Raya Gunung Anyar, Surabaya, Indonesia, 60293
}

Email :fettyanggraeny.if@upnjatim.ac.id ${ }^{1}$, henniendah222@gmail.com ${ }^{2}$,fawwaz_ali.fik@upnjatim.ac.id ${ }^{3)}$, ilhamprasetyaif@gmail.com ${ }^{4)}$,sandyrizkyando@gmail.com ${ }^{5)}$

\begin{abstract}
ABSTRAK
Masa pandemi COVID-19 mengharuskan kegiatan belajar mengajar dilakukan secara daring dari rumah. Perkembangan Teknologi saat ini sangat membantu proses belajar mengajar daring, banyak tools/software yang dapat digunakan. Tools/software yang umum digunakan dalam kegiatan belajar mengajar daring adalah Ms. Word, Ms. Power Point, dan Virtual Lab. Dampak lain dari perkembangan Teknologi ditambah dengan kondisi pandemic menyebabkan interaksi antar manusia lebih banyak dilakukan secara daring melalui perantara internet pada ponsel atau komputer. Saat ini ponsel tidak hanya berfungsi sebagai media komunikasi, beberapa pekerjaan yang sebelumnya diselesaikan menggunakan computer/laptop saat ini dapat diselesaikan menggunakan ponsel pintar. Agar handphone dapat digunakan untuk kegiatan lebih positif dan menunjang proses belajar mengajar, maka dilakukan sharing kepada siswa melalui asah kreativitas desain melalui aplikasi bergerak pada ponsel pintar. Dalam kegiatan ini, siswa mengasah ketrampilan desain grafis menggunakan aplikasi CANVA untuk menunjang proses belajar mengajar. Antusias siswa cukup tinggi, dibuktikan dengan karya yang dihasilkan berupa desain profil pribadi, ekstrakurikuler dan logo. Siswa dapat mempraktekkan dengan baik materi-materi yang disampaikan. Pihak sekolah menyambut baik kegiatan ini, dan menginginkan agar terbentuk ekstrakurikuler Desain Grafis di SMA Dharma Wanita agar dijadikan wadah kreativitas siswa dalam hal desain grafis.
\end{abstract}

Kata kunci: kreativitas digital, desain grafis, canva, ponsel pintar.

\begin{abstract}
During the COVID-19 pandemic, teaching and learning activities must be carried out online from home. The development of technology today really helps the online teaching and learning process, there are many tools / software that can be used. Tools / software commonly used in online teaching and learning activities are Ms. Word, Ms. Power Point, and Virtual Lab. Another impact of technological developments coupled with pandemic conditions has led to more interactions between humans being carried out online through internet intermediaries on cellphones or computers. Currently cellphones do not only function as a medium of communication, some work that was previously completed using a computer / laptop can now be completed using a smart phone. So that cellphones can be used for more positive activities and support the teaching and learning process, sharing is carried out with students through sharpening design creativity through mobile applications on smart phones. In this activity, students hone graphic design skills using the CANVA application to support the teaching and learning process. The enthusiasm of students is quite high, as evidenced by the work produced in the form of personal profile designs, extracurricular activities and logos. Students can practice well the material presented. The school welcomes this activity, and wants to form an extracurricular Graphic Design at SMA Dharma Wanita so that it becomes a forum for student creativity in graphic design.
\end{abstract}

Keywords: digital creativity, graphic design, canva, smartphone. 


\section{Pendahuluan}

Sebagai program studi dalam bidang teknologi informasi, program studi Informatika UPN Veteran Jatim memiliki misi menerapkan ilmu pengetahuan dan teknologi di bidang teknologi informasi melalui kegiatan pengabdian kepada masyarakat.

Perkembangan teknologi informasi dan komunikasi telah membawa banyak dampak bagi kehidupan, diantaranya adalah pada bidang pendidikan. Hadirnya teknologi internet telah merubah cara belajar dan mengajar. Disamping itu perkembangan internet memberi alternatif untuk membantu menata manajemen, utamanya manajemen data. Melalui bantuan teknologi internet, tugas-tugas administrasi dapat dikerjakan lebih efektif dan efisien. Selain perkembangan internet, banyak sekali bermunculan aplikasi-aplikasi yang sangat mudah digunakan oleh pengguna untuk membantu menyelesaikan pekerjaan, tidak terkecuali aplikasi desain grafis.

Desain grafis adalah salah satu bentuk seni lukis (gambar) terapan yang memberikan kebebasan kepada sang designer (perancang) untuk memilih, menciptakan, atau mengatur elemen rupa seperti ilustrasi, foto, tulisan dan garis di atas suatu permukaan dengan tujuan untuk diproduksi dan dikomunikasikan sebagai sebuah pesan. Gambar maupun tanda yang digunakan bisa berupa tipografi atau media lainnya seperti gambar atau fotografi. Desain grafis umumnya diterapkan dalam dunia periklanan packaging, perfilman, dan lain-lain (Riyanto, 2006).

Jika dilihat dari pengertian desain grafis diatas, maka dapat disimpulkan tujuan desain grafis adalah cara berkomunikasi dalam bentuk visual yang menggunakan fasilitas gambar untuk menyampaikan informasi atau pesan se-efektif mungkin. Secara umum, orang akan lebih cepat menerima pesan dalam bentuk visual dibandingkan dalam bentuk teks. Bentuk visual juga lebih universal ditangkap oleh manusia dengan berbagai latar belakang yang berbeda.

Salah satu aplikasi yang ramai digunakan saat ini adalah aplikasi Canva. Canva merupakan salah satu tools yang open source alias gratis dan terbuka untuk umum yang dapat digunakan bahkan bagi pemula. Tak hanya itu, Canva juga dapat diakses melalui perangkat desktop maupun smartphone. Canva selain dikenal sebagai aplikasi desain grafis dalam penggunaannya, juga memiliki keunggulan dibandingkan dengan aplikasi lainnya yang bisa diciptakan antara lain : logo, poster, pembuatan kartu ucapan hari raya, pembuatan media promosi dan sebagainya.

Surat Edaran Menteri Pendidikan dan Kebudayaan Republik Indonesia Nomor 4 Tahun 2020 tentang Pelaksanaan Kebijakan Pendidikan Dalam Masa Darurat Penyebaran Coronavirus Disease (COVID-19) menyebutkan bahwa pada masa pandemi COVID-19 kegiatan belajar mengajar dilakukan secara daring dari rumah sejak Maret 2020 (Mendikbud, 2020). Perkembangan Teknologi saat ini sangat membantu proses belajar mengajar daring, banyak tools/software yang dapat digunakan, tidak hanya di laptop/PC tetapi juga ponsel pintar. Sebelumnya ponsel digunakan untuk media komunikasi, sosial, dan pendidikan (Chusna, 2017). Saat ini manfaat ponsel semakin berkembang dengan bermunculnya ponsel pintar, beberapa pekerjaan yang sebelumnya hanya dapat diselesaikan di komputer/laptop, dapat diselesaikan menggunakan ponsel pintar. Agar handphone dapat digunakan untuk kegiatan lebih positif dan menunjang proses belajar mengajar, maka dilakukan pelatihan asah kreativitas desain grafis menggunakan aplikasi desain grafis pada ponsel pintar.

Kegiatan pengabdian masyarakat ini dilakukan di SMA Dharma Wanita Surabaya. Dalam kegiatan ini, siswa mengasah ketrampilan desain grafis menggunakan aplikasi CANVA untuk menunjang proses belajar mengajar.

\section{Metodologi}

Program Pengabdian Masyarakat Pemanfaatan Ipteks Bagi Masyarakat (PIKAT) 2020 dilaksanakan dalam rentang waktu Agustus-September 2020. Pihak pimpinan sekolah sangat mensupport kegiatan dan memberikan ijin jika diperlukan dilaksanakan secara offline. Tetapi melihat kondisi saat itu yang kurang memungkinkan dan tinggi resiko maka diputuskan kegiatan 
dilaksanakan secara online. Beberapa faktor yang dijadikan dasar pelaksanaan kegiatan secara online antara lain:

1. Kondisi pandemi virus corona.

2. Perlunya ijin dari orangtua secara tertulis untuk siswa melaksanakan kegiatan di sekolah.

3. Jika dilaksanakan secara offline di sekolah bisa terkondisikan melaksanakan protokol, tetapi tidak ada jaminan selesai pelaksanaan kegiatan siswa tetap menjalankan protokol kesehatan sampai kembali lagi ke rumah.

4. Adanya perkembangan teknologi sehingga memudahkan penyampaian materi dan pengumpulan feedback.

5. Siswa yang diikutsertakan kegiatan memiliki hardware (handphone) dengan spesifikasi sesuai kebutuhan untuk terlaksananya kegiatan.

Berdasarkan pertimbangan di atas, maka kegiatan PIKAT dilaksanakan selama kurang lebih satu bulan secara online. Kegiatan terbagi menjadi tiga minggu penyampaian materi dan satu pertemuan penutupan. Materi disampaikan dalam bentuk video singkat, agar siswa mudah untuk memahami materi dan mempraktekkan. Seluruh video materi telah diupload di youtube dan dapat diakses melalui link https://www.youtube.com/channel/ UCMrncgTxTSF6NLsTsdLR-7Q. Karena hasil komunikasi dengan pihak sekolah diputuskan bahwa kegiatan dilakukan secara online, maka perlu dilakukan pemilihan media komunikasi yang paling mudah dan tidak terlalu terhampat dengan jaringan. Maka dalam kegiatan ini digunakan beberapa media komunikasi antara lain:

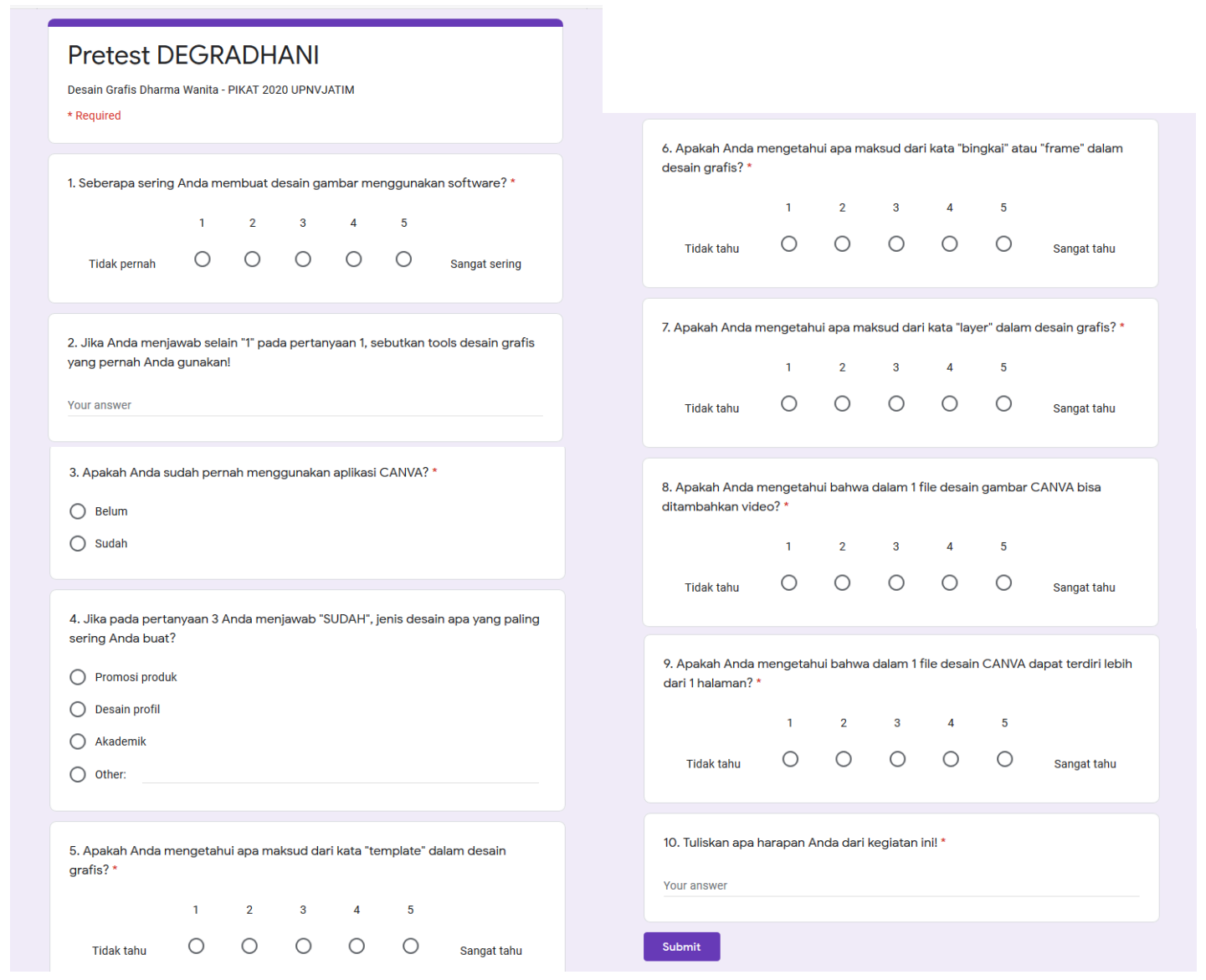

Gambar 1. Kuisioner Pengukuran Kemampuan Desain Grafis Peserta.

a. Grup whatsapp, sebagai media komunikasi utama.

b. Google classroom, sebagai penyimpanan materi dan pengumpulan feedback. 
c. Google form dan Zoho form, digunakan untuk pretest, pendataan kehadiran, posttest, dan testimony.

d. Zoom Meeting dan Google Meet, sebagai sarana tatap muka untuk menggali Informasi umum peserta dan penutupan.

Untuk mengukur hasil kegiatan, dilakukan pengisian kuisioner sebelum pelatihan (minggu pertama) dan sesudah pelatihan (minggu ketiga). Kuisioner dibentuk menggunakan google form, dapat dilihat pada Gambar 1. Poin dari pertanyaan atau pernyataan dalam kuisioner digunakan untuk menggali Informasi dari peserta mengenai pengetahuan tentang desain grafis dan kemampuan melakukan desain grafis digital.

\section{Hasil dan Pembahasan}

Kuisioner dibagikan kepada 21 peserta yang mengikuti kegiatan ini secara lengkap dari awal sampai akhir. Tabel 1 dan 2 serta Gambar 2 menyajikan hasil kuisioner yang memiliki jawaban dengan rentang nilai 1 (TIDAK TAHU) sampai 5 (SANGAT TAHU), dimana pada kolom nilai mencatat jumlah siswa yang memberikan jawaban dari setiap pertanyaan poin kuisioner. Contoh pada poin pertanyaan 1 "Seberapa sering Anda membuat desain gambar menggunakan software?", 7 orang siswa menjawab TIDAK TAHU, 3 siswa menjawab KURANG TAHU, 5 siswa menjawab CUKUP TAHU, 4 siswa menjawab TAHU, dan 5 siswa menjawab KURANG TAHU. Kemudian dihitung rata-rata nilai dengan cara sum(nilai*jumlah_jawaban)/total_kuisioner. Misal untuk poin pertanyaan 1 , rata-rata nilainya $(1 \times 7+2 \times 3+3 \times 5+4 x 4+5 \times 2) / 20=2,57$.

Pada pertemuan pertama, peserta mengisi kuisioner Pretest seputar pengetahuan awal peserta mengenai desain grafis dan kemampuan desain grafis digital, ditampilkan pada Tabel 1. Tabel 2 menampilkan data posttest setelah siswa mengikuti rangkaian kegiatan.

Gambar 2 menunjukkan perbandingan nilai rata-rata dari setiap pertanyaan kuisioner pretest dan posttest yang diisi oleh peserta. Hal ini menunjukkan ada dampak signifikan terhadap pengetahuan peserta Mengenai desain grafis menggunakan aplikasi Canva. Secara rata-rata, pengetahuan dan kemampuan peserta meningkat 1-2 poin rata-rata.

Tabel 1. Hasil Pretest dengan Jawaban Rentang Nilai.

Poin Kuisioner

\begin{tabular}{lllll}
\multicolumn{2}{l}{ Jumlah kuisioner yang memilih nilai } & Rata- \\
\hline & 2 & 3 & 4 & 5
\end{tabular} rata

1. Seberapa sering Anda membuat desain gambar menggunakan software?

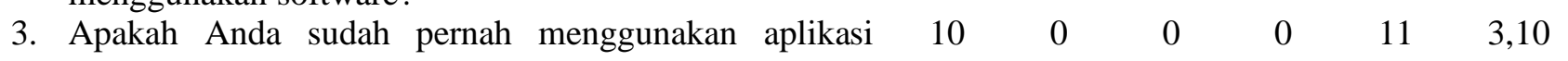
CANVA?

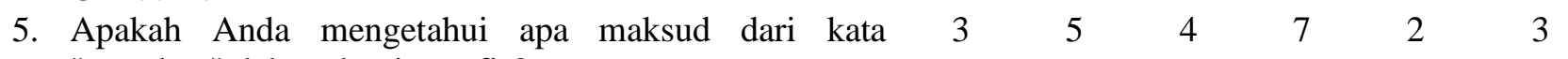
"template" dalam desain grafis?

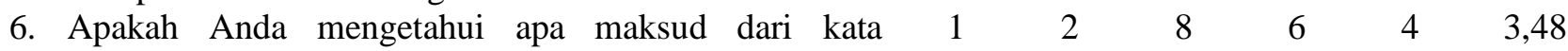

"bingkai" atau "frame" dalam desain grafis?

7. Apakah Anda mengetahui apa maksud dari kata "layer" $\quad \begin{array}{lllllll}6 & 3 & 5 & 4 & 3 & 2,76\end{array}$ dalam desain grafis?

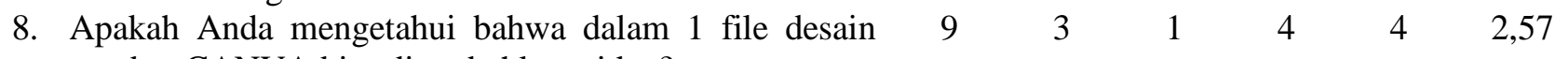
gambar CANVA bisa ditambahkan video?

9. Apakah Anda mengetahui bahwa dalam 1 file desain $\begin{array}{llllllll}8 & 2 & 2 & 4 & 5 & 2,81\end{array}$ CANVA dapat terdiri lebih dari 1 halaman?

\begin{tabular}{ccccccc} 
Jumlah & 44 & 18 & 25 & 29 & 31 & 20,29 \\
Rata-rata & 6,29 & 2,57 & 3,57 & 4,14 & 4,43 & 2,9 \\
\hline
\end{tabular}


Tabel 2. Hasil Postest dengan Jawaban Rentang Nilai

\begin{tabular}{|c|c|c|c|c|c|c|}
\hline \multirow{2}{*}{ Poin Kuisioner } & \multicolumn{5}{|c|}{ Jumlah kuisioner yang memilih nilai } & \multirow{2}{*}{$\begin{array}{c}\text { Rata- } \\
\text { rata } \\
\text { Nilai }\end{array}$} \\
\hline & 1 & 2 & 3 & 4 & 5 & \\
\hline $\begin{array}{l}\text { 1. Seberapa sering Anda membuat desain gambar } \\
\text { menggunakan software? }\end{array}$ & 7 & 3 & 5 & 4 & 2 & 2,57 \\
\hline $\begin{array}{l}\text { 3. Apakah Anda sudah pernah menggunakan aplikasi } \\
\text { CANVA? }\end{array}$ & 10 & 0 & 0 & 0 & 11 & 3,10 \\
\hline $\begin{array}{l}\text { 5. Apakah Anda mengetahui apa maksud dari kata } \\
\text { "template" dalam desain grafis? }\end{array}$ & 3 & 5 & 4 & 7 & 2 & 3 \\
\hline $\begin{array}{l}\text { 6. Apakah Anda mengetahui apa maksud dari kata } \\
\text { "bingkai" atau "frame" dalam desain grafis? }\end{array}$ & 1 & 2 & 8 & 6 & 4 & 3,48 \\
\hline $\begin{array}{l}\text { 7. Apakah Anda mengetahui apa maksud dari kata "layer" } \\
\text { dalam desain grafis? }\end{array}$ & 6 & 3 & 5 & 4 & 3 & 2,76 \\
\hline $\begin{array}{l}\text { 8. Apakah Anda mengetahui bahwa dalam } 1 \text { file desain } \\
\text { gambar CANVA bisa ditambahkan video? }\end{array}$ & 9 & 3 & 1 & 4 & 4 & 2,57 \\
\hline $\begin{array}{l}\text { 9. Apakah Anda mengetahui bahwa dalam } 1 \text { file desain } \\
\text { CANVA dapat terdiri lebih dari } 1 \text { halaman? }\end{array}$ & 8 & 2 & 2 & 4 & 5 & 2,81 \\
\hline $\begin{array}{l}\text { Jumlah } \\
\text { Rata-rata }\end{array}$ & $\begin{array}{c}44 \\
6,29\end{array}$ & $\begin{array}{c}18 \\
2,57\end{array}$ & $\begin{array}{c}25 \\
3,57\end{array}$ & $\begin{array}{c}29 \\
4,14\end{array}$ & $\begin{array}{c}31 \\
4,43\end{array}$ & $\begin{array}{c}20,29 \\
2,9\end{array}$ \\
\hline
\end{tabular}

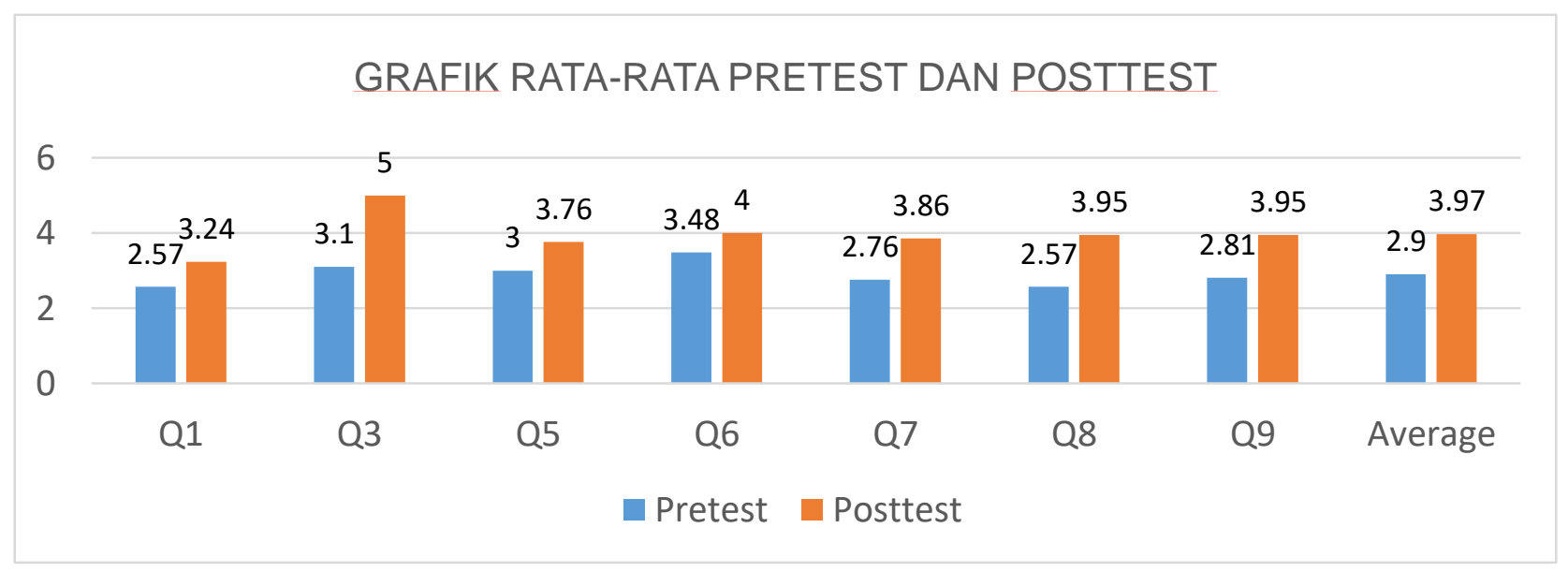

Gambar 2. Perubahan Pengetahuan dan Kemampuan Peserta Sebelum dan Sesudah Mengikuti Kegiatan Pengabdian Masyarakat.

\section{Kesimpulan}

Setelah melakukan seluruh kegiatan dapat diambil kesimpulan, pertama bahwa melalui kegiatan ini, peserta mampu meningkatkan kemampuan dan menambah pengetahuan tentang desain grafis digital. Kedua, ponsel saat ini tidak hanya digunakan sebagai media komunikasi tetapi juga dapat digunakan sebagai alat peningkatan ketrampilan digital dan kegiatan positif yang mendatangkan pendapatan.

\section{Ucapan Terima Kasih}

Terima kasih kepada LPPM Universitas Pembangunan Nasional "Veteran" Jawa Timur Surabaya dan SMA Dharma Wanita Surabaya yang telah membantu terlaksananya program Pemanfaatan IPTEKS bagi Masyarakat (PIKAT) 2020. 


\section{Daftar Pustaka}

Chusna, P.A., 2017. Pengaruh media gadget pada perkembangan karakter anak. Dinamika Penelitian: Media Komunikasi Penelitian Sosial Keagamaan, 17(2), pp.315-330.

Menteri Pendidikan dan Kebudayaan Republik Indonesia. Surat Edaran Nomor 4 Tahun 2020 tentang Pelaksanaan Kebijakan Pendidikan Dalam Masa Darurat Penyebaran Coronavirus Disease (COVID-19). https://www.kemdikbud.go.id/main/blog/2020/03/se-mendikbudpelaksanaan-kebijakan-pendidikan-dalam-masa-darurat-penyebaran-covid19

Riyanto, S. (2006). Bagaimana memulai belajar Desain Grafis?. 2 November 2020. https://ilmukomputer.org/2006/12/27/bagaimana-memulai-belajar-desain-grafis/ 